\title{
Eight new records of monogonont and bdelloid rotifers from Korea
}

\author{
Min Ok Song* \\ Department of Biology, Gangneung-Wonju National University, Gangwon-do 201-702, Korea \\ *Correspondent: rotisong@gmail.com,minsong@gwnu.ac.kr
}

\begin{abstract}
The rotifers collected from a brackish water zone as well as various terrestrial habitats such as mosses, lichens, and leaf litter at seven different locations in Korea were investigated. Eight species/subspecies belonging to five genera in five families of monogonont and bdelloid rotifers new to Korea were identified: Encentrum incisum, Encentrum uncinatum, Cephalodella innesi, Adineta gracilis, Macrotrachella timida timida, Macrotrachella timida inquies, Habrotrocha pavida and Habrotrocha scabropyga. Five bdelloids are new to Asia as well. Notably, these eight Korean new records included three rare species. H. scabropyga is recorded outside its type locality for the first time. For M. timida timida, this study is the third record after its description. In addition, E. incisum has been reported only from Austria, Germany and Russia before the present study.
\end{abstract}

Keywords: brackish and terrestrial habitats, Korea, new records, Rotifera, taxonomy

(C) 2014 National Institute of Biological Resources

DOI: $10.12651 /$ JSR.2014.3.1.053

\section{INTRODUCTION}

Owing to their ability to withstand harsh periods through anhydrobiosis, bdelloids can dwell in the water film covering terrestrial mosses, lichens, and soil, and be found in extraordinary habitats such as plant debris and wild mushrooms. This distinguishing feature makes them pioneering animals, able to colonize new environments ( $\mathrm{Ri}-$ cci, 1987; Nogrady et al., 1993). In the present study, two monogononts, E. incisum Wulfert, 1936 and E. uncinatum (Milne, 1886), were also found in some of these terrestrial habitats. It has been reported that several dicranophorids including E. mucronatum Wulfert, 1936, E. incisum and E. mustela (Milne, 1885) are dwelling in mosses on the ground, trees, holes in tree stumps, leaf litter and the top centimeters of different soils (De Smet, 1995).

Bdelloids have a vermiform body with pseudosegmentation that permits telescopic shortening and expansion, and well-developed paired trochal discs (corona), which are used in locomotion as well as food gathering. The taxonomy of bdelloids is based primarily on the morphology of alimentary system, corona, trophi, spurs, toes and body ornaments such as spines or cuticular knobs. Especially, the shape of corona, sulcus, upper lip and disc retractor are rather species-specific and very important diagnostic characters (Song, 1999). Since these characteristics can be observed only in creeping or feeding condition, bdelloids must be identified in live state, and it's almost impossible to identify bdelloids preserved without narcotization. This may explain the poor record of bdelloids not only from Korea, but throughout the world.

Phylum Rotifera comprises about 2100 species/subspecies including about 1600 monogononts and 460 bdelloids (Segers, 2007; Jersabek and Leitner, 2013). To date, approximately 142 monogononts and 52 bdelloids have been reported from Korea (The Korean Society of Systematic Zoology, 1997; Song and Jin, 2000; Song and Kim, 2000). This record is still much lower than the substantial body of worldwide reports. Apparently, further taxonomic studies on rotifers are urgently required in Korea.

Here we report on eight new records of Korean rotifers with redescriptions and illustrations. We also present notes on the distribution of some rare species.

\section{Materials and Methods}

For the present taxonomic study on Korean rotifers, specimens collected from a brackish water zone as well as various terrestrial habitats such as mosses, lichens and leaf litter were investigated. Samples were collected from seven locations in Korea from Feb. 26 to Oct. 17, 2013. The detailed habitat information and sampling date of each locality are listed in Table 1 .

For the extraction of bdelloids from mosses, lichens and leaf litter, samples were soaked in tap or deionized 
water for several hours or overnight depending on the dehydration state of the samples. The samples were agitated to detach any bdelloids from the surfaces of plants or plant debris, and then the plant material was squeezed and removed. After further removal of the particles and debris using a sieve of $1.2 \mathrm{~mm}$ mesh-size, the supernatant of wash water was filtered through a fine nylon membrane of $60 \mu \mathrm{m}$ mesh-size. Brackish water samples were concentrated using a nylon membrane of $60 \mu \mathrm{m}$ mesh-size as well. The filtered specimens on the membrane were transferred to a petri dish.

All rotifers were examined and identified alive under a light microscope with a magnification of $400 \times$. All living specimens were recorded and photographed using Infinity 2 digital camera (Nikon). Both the photos and the computer-grabbed images were used for illustration. Measurements were made with Photoshop CS3. The boiling water fixation method (Pennak, 1978), instead of narcotics, was used to kill specimens with head, foot and toes extended. For preparation of permanent mounts, the method of Stemberger (1979) was used.

The classification scheme is based on Melone and Ricci (1995) for bdelloids, and De Smet (1997) and Nogrady and Pourriot (1995) for monogononts.

\section{Results AND Discussion}

As a result of the present study, three monogononts and five bdelloids are newly recorded from Korea: Encentrum incisum, E. uncinatum, Cephalodella innesi Myers, 1924, Adineta gracilis Janson, 1893, Macrotrachella timida timida Milne, 1916, M. timida inquies Milne, 1916, Habrotrocha pavida Bryce, 1915 and H. scabropyga Bartoš, 1958. These five bdelloids are new to Asia as well. Notably, these eight Korean new records included three rare species. $H$. scabropyga has never been reported again since its original description by Bartoš (Bartoš, 1959) until the present study. M. timida timida was reported only from Czech Republic after its description in South Africa by Milne (1916), and E. incisum has been restricted to three countries, Germany, Austria and Russia, so far (De Smet, 1997).

Here we present these eight Korean new records of rotifers with redescriptions and illustrations. We also comment on the taxonomy and distribution of those rare species.

Phylum Rotifera Cuvier, 1817

Class Eurotatoria De Ridder, 1957

Subclass Monogononta Plate, 1889

Order Ploima Hudson and Gosse, 1886

Family Dicranophoridae Harring, 1913

Genus Encentrum Ehrenberg, 1838

\section{Encentrum incisum Wulfert, 1936 (Fig. 1A-C)}

Encentrum incisum Wulfert, 1936, pp. 423-425, figs. 16, 16 a-c (cited from De Smet, 1997); Donner, 1970, p. 226, figs. 13e-f; Koste, 1978, p. 495, pl. 176, figs. 1 a-e; De Smet, 1997, pp. 182-184, figs. 503-507, pl. 31, figs. 1-5; Jersabek, 1998, pp. 67-69, figs. 21-24.

Material examined. 2 specimens, a mountain in Gyo-1dong, Gangneung-si, Gangwon-do (leaf litter, Min Ok Song), 26 Feb, 2013.

Description. Body spindle-shaped. Head about $1 / 2$ of trunk length. Integument thin, smooth, transparent and with transverse folds defining head, trunk and foot. Rostrum short, V-shaped ventrally and decurved. Foot conical, short and about $1 / 6$ of trunk length. Toes short, slender, about same length as foot, parallel-sided until half of length and tapering to pointed tips.

Trophi forcipate type. Rami outline round pyriform, each getting broader until 1/3 from base, abruptly tapering into slender and incurved single tooth after preuncinal tooth; preuncinal tooth long, narrow and sharp, emerging from outer margin of ramus ventrally and projecting towards axis of trophi; another preuncinal tooth present between apical tooth and ventral preuncinal tooth. Fulcrum short, about $2 / 5$ of manubria length. Intramallei short, with round base and tapering ends. Unci stout, single-toothed, about 3/5 of manubria length. Manubria rodshaped, long, longer than 2-fold of fulcrum length, incurved, knobby distally and expanded proximally.

Body length $202 \mu \mathrm{m}$. Toe length $19 \mu \mathrm{m}$.

Distribution. Austria, Germany, Russia and Korea.

Remarks. E. incisum has been reported only from Austria, Germany and Russia before the present study (De Smet, 1997). It is similar to E. martoides Fott, 1960 except the following differences: (1) Foot of E. incisum has a single pseudosegment, while that of $E$. martoides has two pseudosegments, (2) Inner margin of rami is outcurved near posterior 1/3 in E. incisum, while it is otherwise in E. martoides, and (3) Gastric glands of E. incisum are not fused nor connected with brain, while they are fused dorsally and connected with brain in E. martoides (De Smet, 1997).

\section{Encentrum uncinatum (Milne, 1886) (Fig. 1D-F)}

Diglena uncinata Milne, 1886, p. 141, pl. 2, figs. 1, 2, 8.

Dicranophorus uncinatus: Donner, 1964, pp. 283-284, figs. 20a-d; Koste, 1978, p. 466, pl. 169, figs. 12a-d, pl. 172, figs. 7a-d.

Encentrum uncinatum: De Smet, 1997, p. 161, figs. 434440, pl. 25, figs. 1-4.

Material examined. 8 specimens, a mountain in Gyo-1dong, Gangneung-si, Gangwon-do (leaf litter, Min Ok Song), 26 Feb, 2013. 
Table 1. List of sampling localities.

\begin{tabular}{|c|c|c|c|c|}
\hline Locality & GPS coordinates & Sampling date & Habitat & Species \\
\hline $\begin{array}{l}\text { 1. A mountain in Gyo-1-dong, } \\
\text { Gangneung-si, Gangwon-do }\end{array}$ & $\begin{array}{l}37^{\circ} 45^{\prime} 56.07^{\prime \prime} \mathrm{N} \\
128^{\circ} 52^{\prime} 29.01^{\prime \prime} \mathrm{E}\end{array}$ & Feb. 26, 2013 & Leaf litter & $\begin{array}{l}\text { E. incisum, } \\
\text { E. uncinatum }\end{array}$ \\
\hline 2. Hakik-dong, Incheon-si & $\begin{array}{l}37^{\circ} 26^{\prime} 23.55^{\prime \prime} \mathrm{N} \\
126^{\circ} 39^{\prime} 8.63^{\prime \prime} \mathrm{E}\end{array}$ & Oct. 17,2013 & Brackish water & C. innesi \\
\hline $\begin{array}{l}\text { 3. A mountain in Jukheon-dong, } \\
\text { Gangneung-si, Gangwon-do }\end{array}$ & $\begin{array}{l}37^{\circ} 46^{\prime} 52.83^{\prime \prime} \mathrm{N} \\
128^{\circ} 51^{\prime} 22.42^{\prime \prime} \mathrm{E}\end{array}$ & March 7, 2013 & Mosses and lichens & A. gracilis \\
\hline 4. Hong-do, Sinan-gun, Jeonranam-do & $\begin{array}{l}34^{\circ} 41^{\prime} 35.67^{\prime \prime} \mathrm{N} \\
125^{\circ} 12^{\prime} 3.99^{\prime \prime} \mathrm{E}\end{array}$ & July 2, 2013 & Mosses and soil & M. timida timida \\
\hline $\begin{array}{l}\text { 5. Wanggok-ri, Goseong-gun, } \\
\text { Gangwon-do }\end{array}$ & $\begin{array}{l}38^{\circ} 22^{\prime} 48.46^{\prime \prime} \mathrm{N} \\
128^{\circ} 28^{\prime} 2.78^{\prime \prime} \mathrm{E}\end{array}$ & Sep. 15,2013 & Mosses on a tree trunk & M. timida inquies \\
\hline $\begin{array}{l}\text { 6. A mountain in Mongsanpo, Seosan-si, } \\
\text { Chungcheongnam-do }\end{array}$ & $\begin{array}{l}36^{\circ} 47^{\prime} 4.20^{\prime \prime} \mathrm{N} \\
126^{\circ} 27^{\prime} 1.14^{\prime \prime} \mathrm{E}\end{array}$ & April 14, 2013 & Mosses and leaf litter & H. pavida \\
\hline $\begin{array}{l}\text { 7. A mountain in Jeongan-myun, } \\
\text { Gongju-si, Chungcheongnam-do }\end{array}$ & $\begin{array}{l}36^{\circ} 36^{\prime} 30.86^{\prime \prime} \mathrm{N} \\
127^{\circ} 7^{\prime} 12.42^{\prime \prime} \mathrm{E}\end{array}$ & April 14, 2013 & Mosses & H. scabropyga \\
\hline
\end{tabular}

Description. Body elongate, half-moon-shaped and flattened laterally. Trunk subcylindrical, rather flat ventrally, convex dorsally, and with laterodorsal longitudinal folds. Transverse folds defining body into head, trunk and foot. Integument thin, smooth and transparent, but body outline rather fairly constant. Head big, about $2 / 5$ of body length except toes. Eye-spots absent. Rostrum large, broad, triangular and decurved. Foot conical and 1/3 of trunk length. Toes sword-shaped, long and about 2-fold of foot length. Retrocerebral sac and duct present. Trophi forcipate type. Rami outline pyriform, each sickle-shaped and terminating into a long, tapering and incurved tooth; a needle-like preuncinal tooth emerging from outer margin and projecting towards axis of trophi at about $1 / 3$ from a tip. Fulcrum short, about $1 / 3$ of ramus length. Unci single-toothed, about 3/5 of manubria length. Intramallei short, with round base and tapering ends. Supramanubria large, thin, rhomboid-ovate and tapering into short needlelike tips distally. Manubria long, about 3-fold of fulcrum length, rod-shaped, curved and knobby distally and proximally.

Body length $250 \mu \mathrm{m}$, toe length $70 \mu \mathrm{m}$; trophi length $30 \mu \mathrm{m}$.

Distribution. Cosmopolitan, but, not recorded from Korea before.

Remarks. De Smet (1997) proposed that the genus Dicranophorus should only include species characterized by: elongate basal and subbasal chambers forming a dense conglomerate; basal chamber opening laterally; subbasal chamber opening ventrally; intramallei absent; unci single-toothed, interlocking with dorsal apical ramus tooth or its cardal apophyse and a cardal apophyse ventrally. Since the trophi parts of Dicranophorus uncinatus have characteristics different from those mentioned above, De Smet (1997) transferred it to genus Encentrum.
Family Notommatidae Remane, 1933

Genus Cephalodella Bory de St. Vincent, 1826

\section{Cephalodella innesi Myers, 1924 (Fig. 1G-I)}

Cephalodella innesi Myers, Harring and Myers, 1924, p. 470, figs. 26: 3-5; Nogrady and Pourriot, 1995, p. 92, Fig. 123.

Material examined. 5 specimens, brackish water, Hakikdong, Incheon-si (Gi Sik Min), 17 Oct, 2013.

Description. Body elongate, slightly compressed laterally and gibbous dorsally; head and foot clearly defined. Head about a third of body length. Corona oblique and convex without projecting lips. Integument smooth, thin and flexible; lorica plate absent. Eye spots red, double, frontal and wide apart each other. Foot about a seventh of body length, conical, and with a short tail. Toes longer than foot, slender, and tapering gradually to pointed tips; ratio of total body length / toe length about 4.5. Trophi virgate type; manubria long and crutched.

Body length $138-144 \mu \mathrm{m}$. Toe length $24-25 \mu \mathrm{m}$. Trophi length $43 \mu \mathrm{m}$. Fulcrum length $29 \mu \mathrm{m}$.

Distribution. USA, Spain, Thailand, Tibet, Korea.

Remarks. This species has been reported from Balearic archipelago, Spain (De Manuel et al., 1992), Thailand (Chittapun et al., 1999), Tibet (reviewed in Zhuge et al., 1998) since its original description from USA by Myers (Haring and Myers, 1924).

Subclass Bdelloidea Hudson, 1884

Order Adinetida Melone and Ricci, 1995

Family Adinetidae Bryce, 1910

Genus Adineta Hudson and Gosse, 1886

4. Adineta gracilis Janson, 1893 (Fig. 2A)

Adineta gracilis Janson, 1893, p. 77, pl. 5, figs. 76, 77; 
A

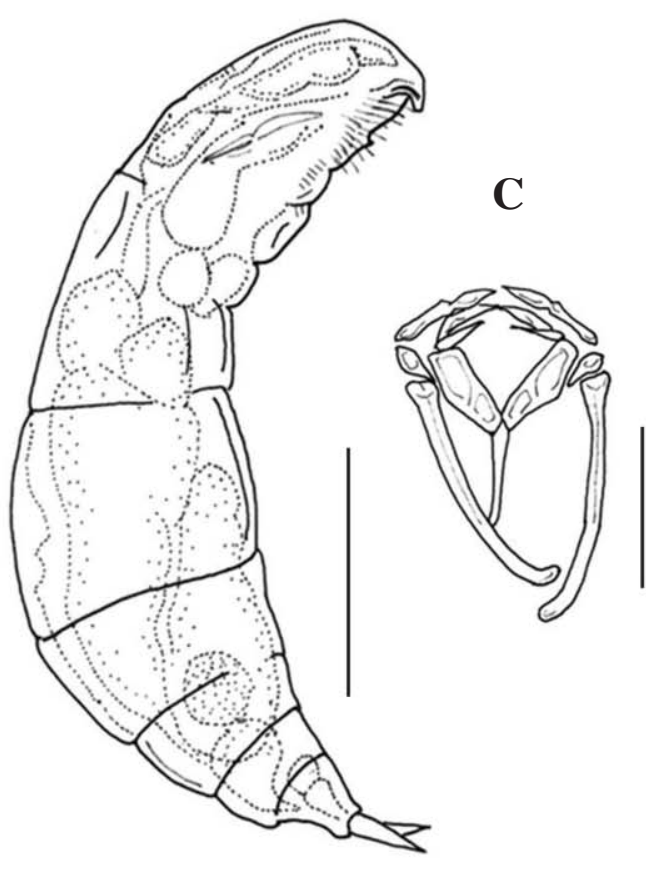

D
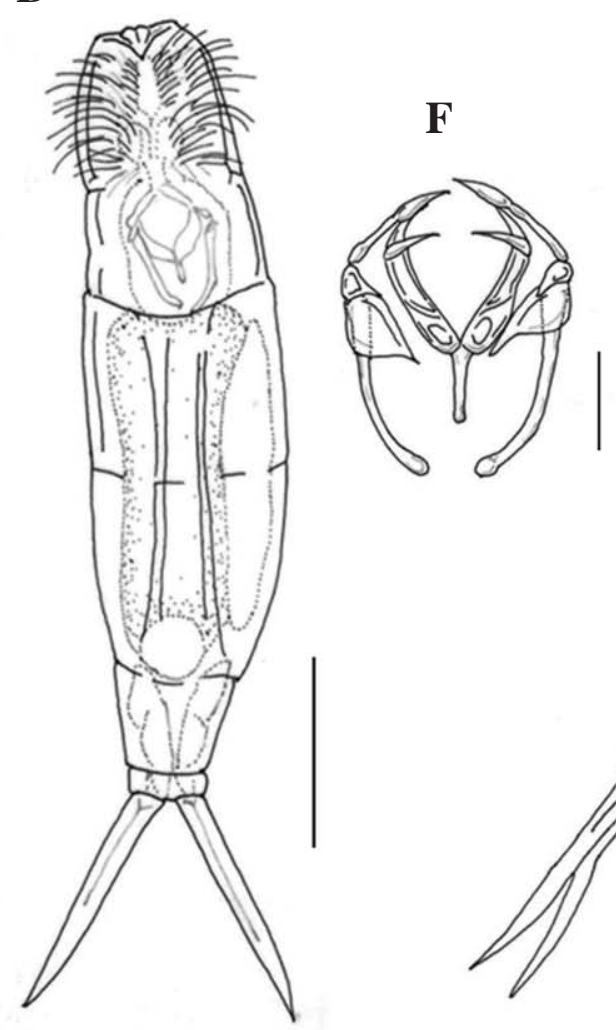

B

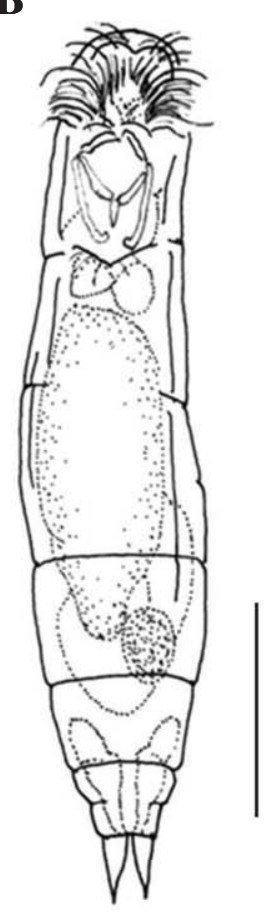

G

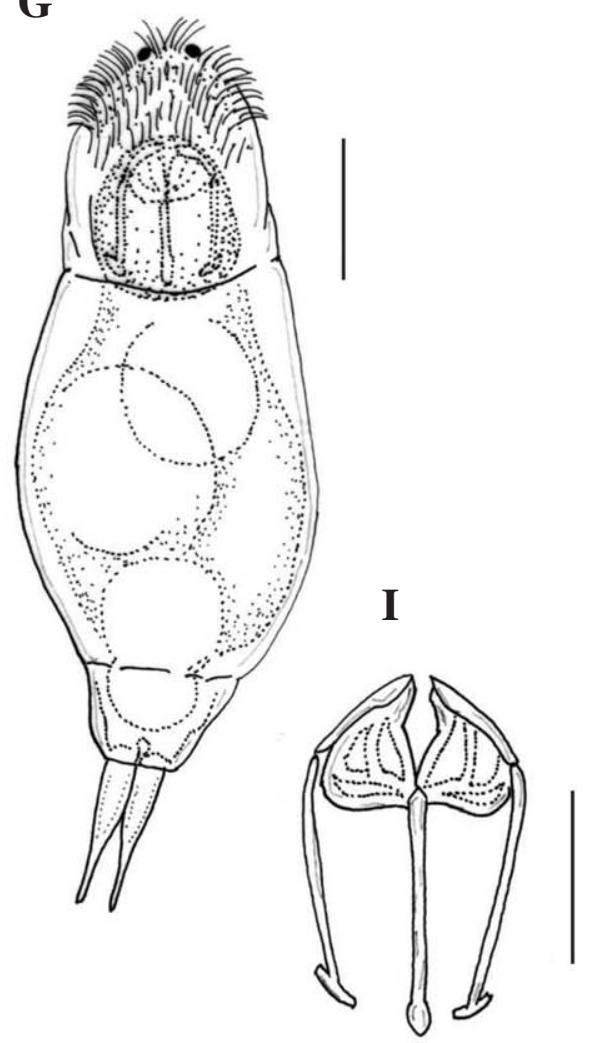

E
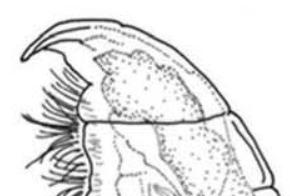

H

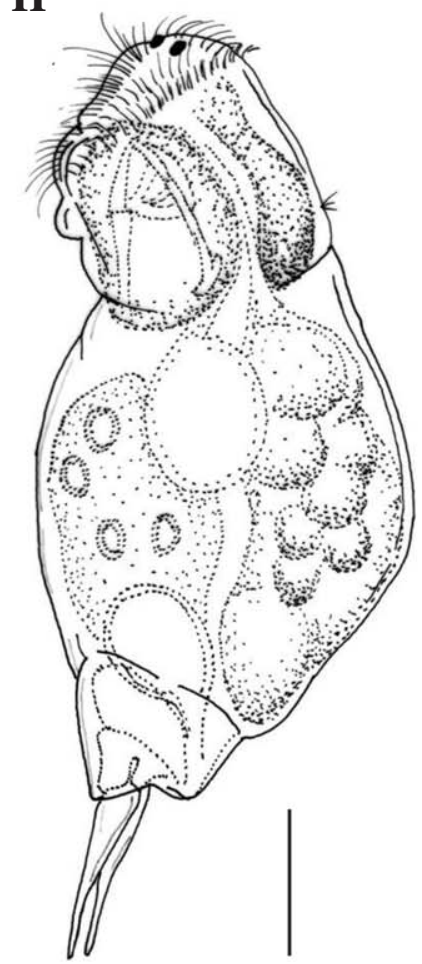

Fig. 1. Encentrum incisum Wulfert, 1936. A. lateral view. B. ventral view. C. trophi, ventral view. Encentrum uncinatum (Milne, 1886). D. ventral view. E. lateral view. F. trophi, ventral view. Cephalodella innesi Myers, 1924. G. ventral view. H. lateral view. I. trophi, ventral view (Scales: A, B, D, E=50 $\mu \mathrm{m} ; \mathrm{C}, \mathrm{F}=10 \mu \mathrm{m} ; \mathrm{G}-\mathrm{I}=20 \mu \mathrm{m}$ ). 
Montet, 1915, p. 262, pl. 7, figs. 1a, b; Bartoš, 1951, p. 477, figs. 4B, 66D, H; Bartoš, 1959, p. 309, figs. 57 D-E; Donner, 1965, p. 274, figs. 199g-j.

Material examined. 8 specimens, a mountain in Jukheondong, Gangneung-si, Gangwon-do (moss and lichens, Chang-Ho Lee), 07 March, 2013.

Description. Eyes absent. Head oval, flat and thumbshaped. Rostrum lamella like brim of hat, with even height and without auricle-like structure laterally, incurved ventrally. Corona a ventral ciliary field and non-retractable. Rake apparatus absent. Two thin and long spine-like projections present anterior to mouth; each tip curved and pointing up. Integument around posterior part of ventral ciliary field and mouth extended like lamella forming rhomboidal collar-shaped structure. Dental formula $2 / 2$. Preanal segment much narrower than preceding segment of trunk. Anal segment gradually tapering to foot. Foot
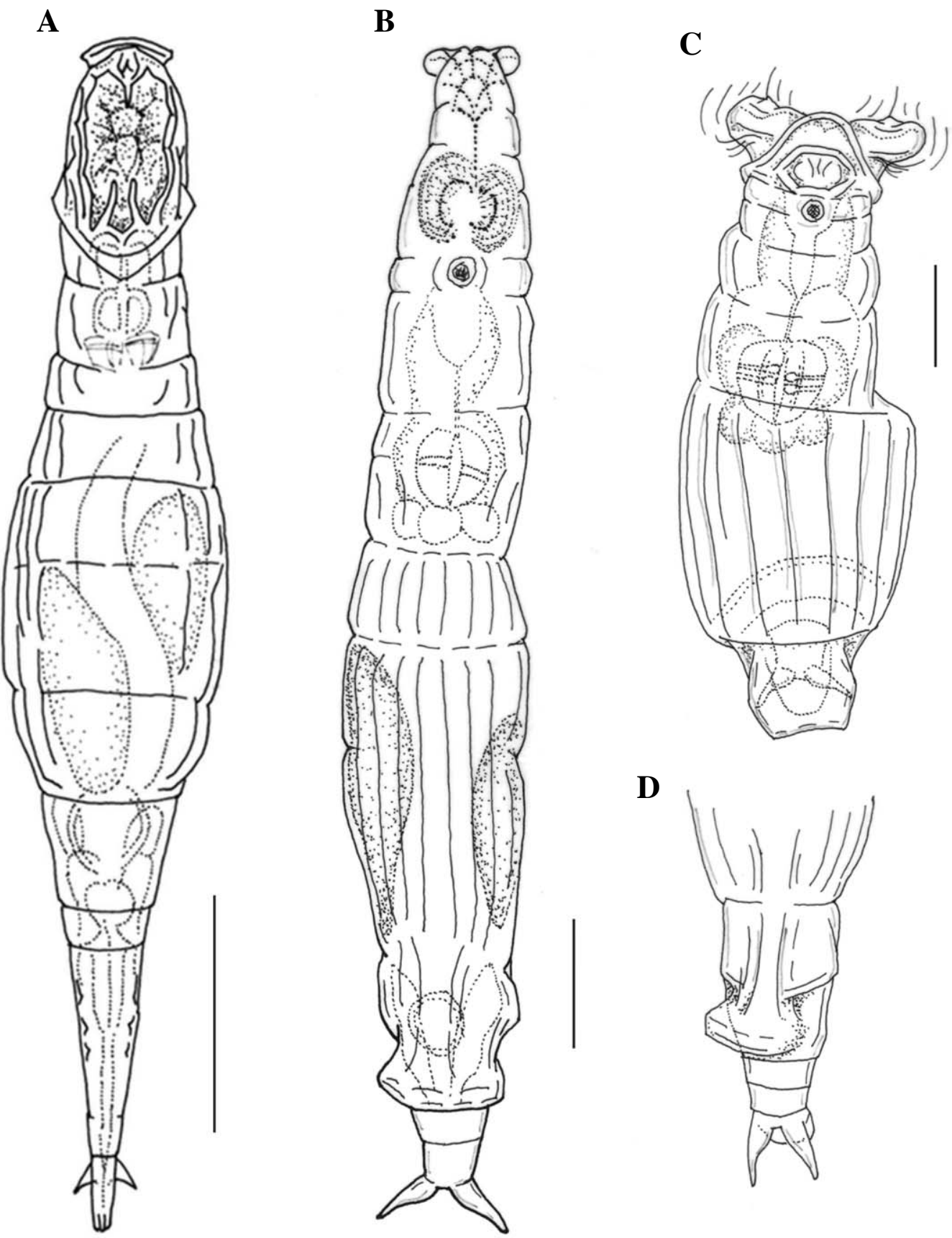

D

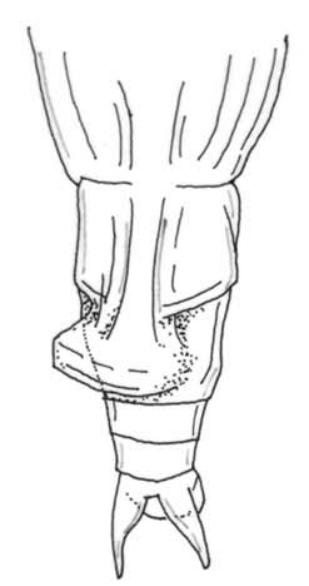

Fig. 2. A. Adineta gracilis Janson, 1893, ventral view. Macrotrachela timida timida Milne, 1916. B. creeping, dorsal view. C. feeding, dorsal view. D. rump, foot and spurs, dorsal view (Scales: $A=50 \mu \mathrm{m} ; \mathrm{B}-\mathrm{C}=20 \mu \mathrm{m}$ ). 
narrower than rump. Spurs small, triangular and decurved towards end. Three toes small.

Body length $256 \mu \mathrm{m}$. Trunk width $41 \mu \mathrm{m}$.

Distribution. Europe, Australia, New Zealand, Pacific Islands, the Antarctic, South and North America, and Korea.

Remarks. Cosmopolitan, but, new to Asia.

Order Philodinida Melone and Ricci, 1995

Family Philodinidae Bryce, 1910

Genus Macrotrachela Milne, 1886

5. Macrotrachela timida timida Milne, 1916 (Fig. 2B-D) Macrotrachela timida timida Milne, 1916, pp. 152-154, Figs. 3-3a; Donner, 1965, p. 155, figs. 114a-b.
Material examined. 2 specimens, Hong-do, Sinan-gun, Jeonranam-do (mosses and soil, Chang-Ho Lee), 2 July, 2013.

Description. Body with smooth surface. Rostral lamella wider than rostrum end and quadruple-lobed; lateral lobes bigger than median ones and like auricles. Corona wider than cingulum pad. Upper lip rimmed and as high as disc retractor; with somewhat concave sides and U-shaped median lobe. Disc retractor bilobed. Dental formula 2/2. Rump 'crinoline-type' and with two deep longitudinal folds in the middle dorsally; anal segment extended dorsally forming like a hexagonal flange. Foot with four segments and three toes. Spurs conical, divergent, and somewhat longer than spur segment width; outer margin slightly convex; inner margin swollen like a shoulder until 1/3
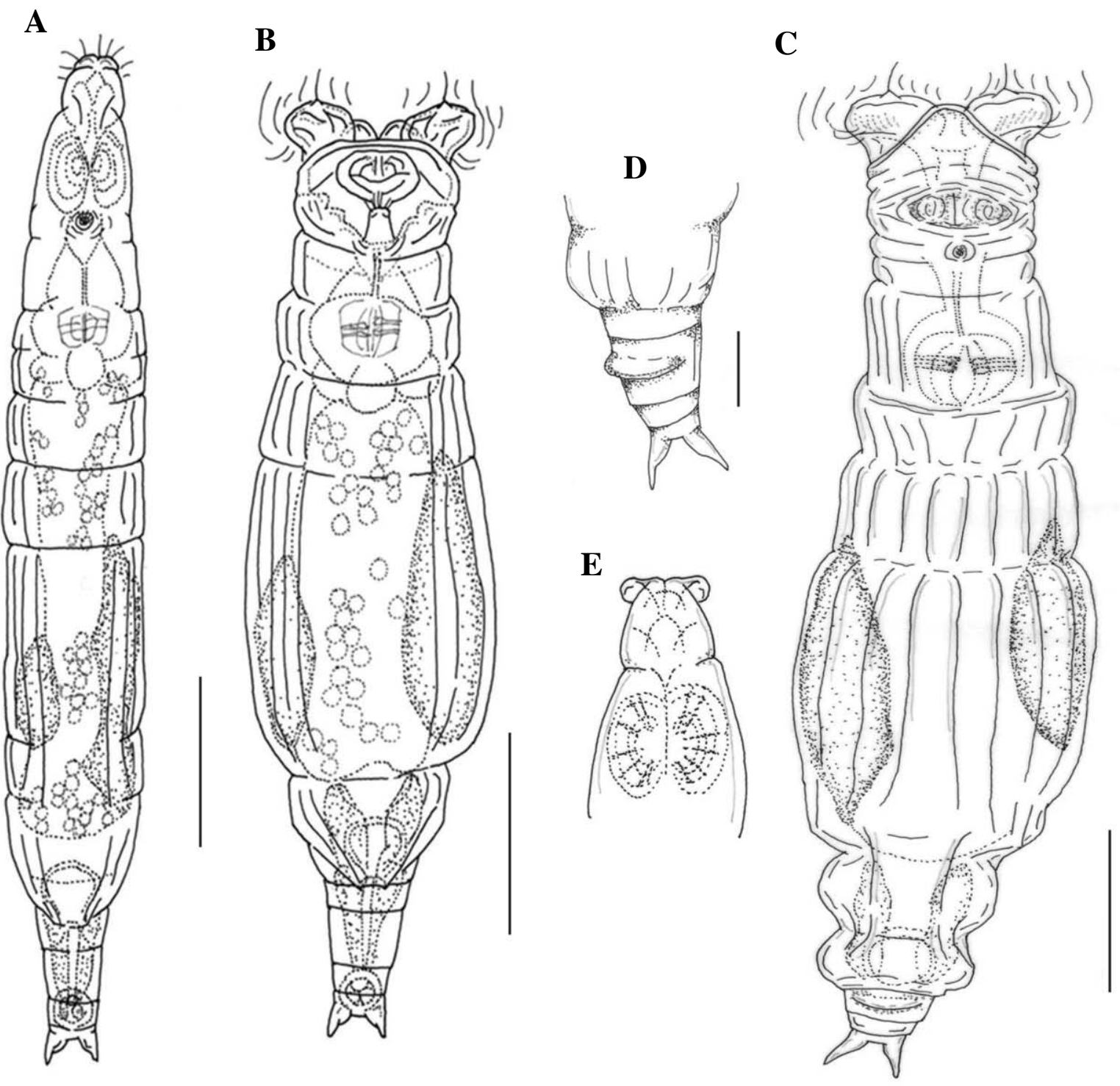

Fig. 3. Habrotrocha scabropyga Bartoš, 1958. A. creeping, dorsal view. B. feeding, dorsal view. Macrotrachela timida inquies Milne, 1916. C. feeding, dorsal view. D. rump, foot and spurs, dorsolateral view. E. rostrum and neck, dorsal view (Scales: A-C=50 $\mu \mathrm{m}$; $D=20 \mu \mathrm{m}$ ). 
from base and then abruptly tapering to narrow end; interspace narrower than spur base width.

Body length (in creeping) $205 \mu \mathrm{m}$. Trunk width (in creeping) $30 \mu \mathrm{m}$. Corona width $39 \mu \mathrm{m}$. Cingulm pad width $30 \mu \mathrm{m}$. Spur length $10 \mu \mathrm{m}$.

Distribution. South Africa, Czech Republic and Korea. Remarks. New to Asia. After Milne (1916) described this species from South Africa, it has been reported only from Czech Republic (SüdMähren, Pollauer Berge) by Donner $(1954 ; 1965)$ until the present study.

\section{Macrotrachela timida inquies Milne, 1916 (Fig. 3C-E)} Macrotrachela timida inquies Milne, 1916, pp. 154-155, pl. 10, Fig. 4; Bartoš, 1959, pp. 251-252, figs. 38M, O; Donner, 1965, pp. 155-156, fig. 114c; Donner, 1972, pp. 104-105, figs. 91; Donner, 1980, p. 139, fig. 5d.

Material examined. 5 specimens, Wanggok-ri, Goseonggun, Gangwon-do (mosses on a tree trunk, Min Ok Song), 15 Sep., 2013.

Description. Body with smooth surface. Rostral lamella wider than rostrum end and quadruple-lobed; lateral lobes bigger than median ones and like auricles. Corona wider than cingulum pad. Upper lip rimmed, as high as disc retractor, with somewhat concave sides and with arched median lobe. Dental formula 2/2. Rump 'crinoline-type' and with two deep longitudinal folds in the middle dorsally; dorsal expansion of anal segment not as prominent as that of $M$. timida timida. Foot with four segments and three toes; first foot segment with a transverse protuberance dorsally. Spurs conical, divergent, as long as spur segment width; inner margin somewhat swollen like a shoulder until 1/3 from base and then gradually tapering to narrow end; interspace slightly narrower than spur base width.

Corona width $49 \mu \mathrm{m}$. Cingulum pad width $41 \mu \mathrm{m}$. Spur length $15 \mu \mathrm{m}$.

Distribution. South Africa, Austria, Czech Republic, Spain, Brazil and Korea.

Remarks. The present subspecies is different from $M$. timida timida as follows: (1) It has a transverse protuberance on the first foot segment dorsally, while $M$. timida timida does not have any dorsal bump or projection on foot; (2) The dorsal expansion of anal segment is not as noticeable as that of $M$. timida timida; (3) Spurs of the present subspecies is as long as its base width, while those of $M$. timida timida are longer than spur base width. New to Asia.

Family Habrotrochidae Bryce, 1910

Genus Habrotrocha Hudson and Gosse, 1886

7. Habrotrocha pavida Bryce, 1915 (Fig. 4)

Habrotrocha pavida Bryce, 1915, p. 637, pl. 38, fig. 2;
Bartoš, 1951, p. 318, figs. 21A-C; Bartoš, 1959, p. 144, figs. 17D-F; Donner, 1950, pp. 316-318, figs. 15a-e; Donner, 1965, pp. 40-41, Fig. 21.

Material examined. 2 specimens, a mountain in Mongsanpo, Seosan-si, Chungcheongnam-do (mosses and leaf litter, Min Ok Song), 14 April, 2013.

Description. Inhabiting irregular shaped shelter or nest of mucus, detritus and extruded food pellets. Body with smooth surface. Rostrum rather short. Rostral lamella small, narrower than rostrum end and bilobed. Corona wider than cingulum pad. Upper lip lower than sulcus, rimmed, arched, and with triangular median lobe; each side of upper lip expanded like auricle. Disc retractor bilobed with convex sides and as high as trochal discs. Antenna rather short and with very prominent process on each side; each protuberance with expanded end. Pharyngeal tube as long as trophi length. Dental formula 4/4. Trunk spindle-shaped and with distinct longitudinal folds. Rump abruptly tapering into foot. Foot with 3 segments and 3 toes; first foot segment with a round process dorsally. Spurs finger-shaped, long, thin, about 3 times as long as its base, tapering gradually from base to blunt tip; interspace 2 times as wide as spur base.

Body length (in creeping) 280-285 $\mu \mathrm{m}$. Corona width $47 \mu \mathrm{m}$. Cingulum pad width $35 \mu \mathrm{m}$. Antenna segment width $35 \mu \mathrm{m}$. Spur length $19 \mu \mathrm{m}$.

Distribution. Germany, Czech Republic, England, Austria, Rumania, North America and Korea.

Remarks. New to Asia. This species is very similar to H. gracilis in the general body structure and the same habit of taking shelter or nest in any available aggregations of debris, but it is distinguished from the latter by the following characteristics; (1) Cingulum of the present species has bulging lateral margins as well as a triangular median lobe, while that of the latter does not, (2) The first foot segment of the present species has a round process dorsally, while that of the latter has two transverse protuberances anterodorsally, (3) Disc retractor of the present species does not have any process medially, while that of the latter has three ones, and (4) Spurs of the present species are longer and thinner than those of the latter.

\section{Habrotrocha scabropyga Bartoš, 1958 (Fig. 3A-B)} Habrotrocha scabropyga Bartoš, 1958, p. 71, Figs. A-C (From Bartoš, 1959, p. 149, Figs. 19A, B, F); Donner, 1965, pp. 53-54, Figs. 39c-d.

Material examined. 2 specimens, a mountain in Jeonganmyeon, Gongju-si, Chungcheongnam-do (mosses, Min Ok Song), 14 April, 2013.

Description. Body with smooth surface. Rostrum rather short. Rostral lamella small, as wide as rostrum end and bilobed. Corona wider than cingulum pad. Upper lip lower 


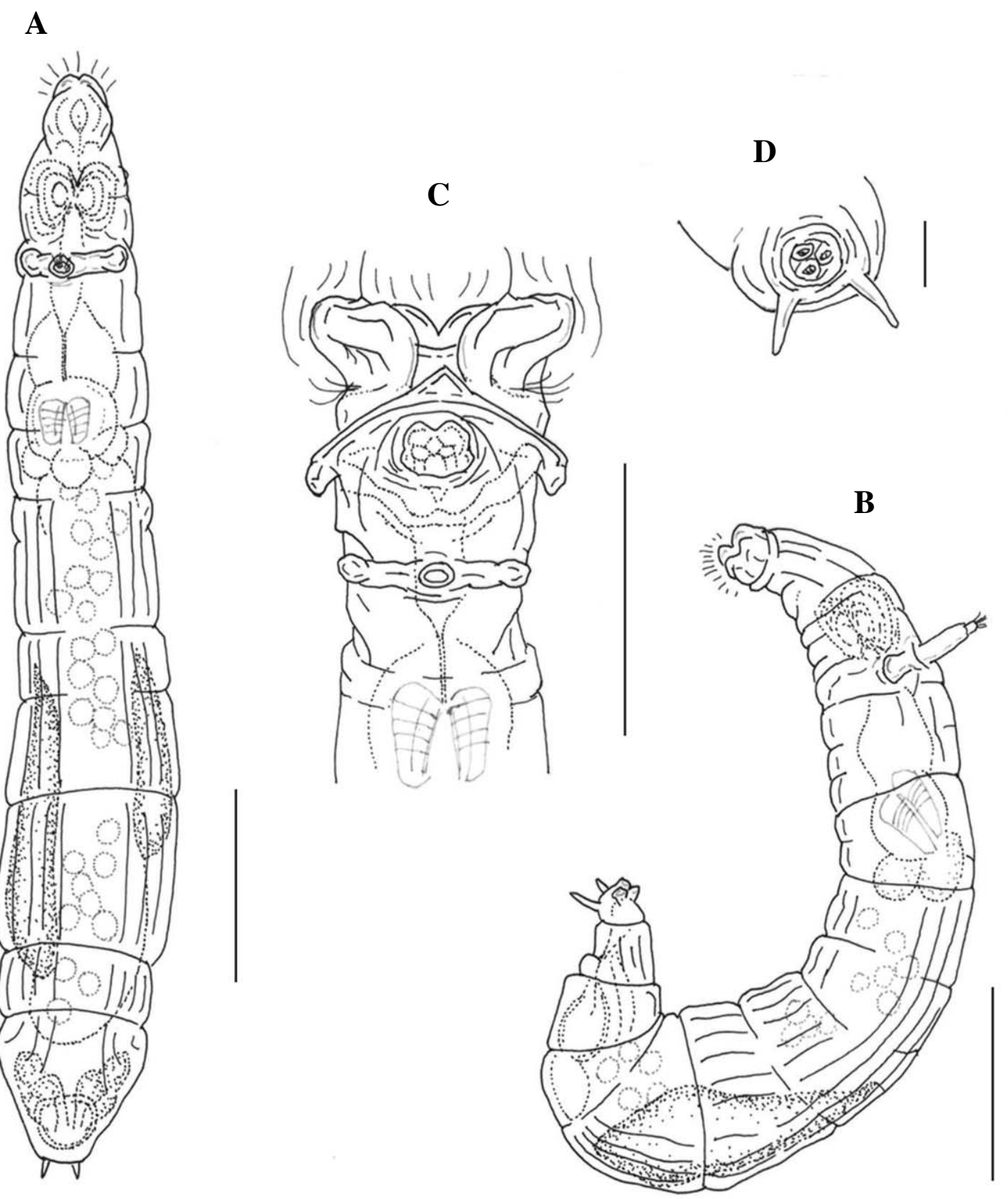

Fig. 4. Habrotrocha pavida Bryce, 1915. A. creeping, dorsal view. B. creeping, lateral view. C. feeding head and neck, dorsal view. D. spurs and toes, ventral view (Scales: A-C $=50 \mu \mathrm{m} ; \mathrm{D}=20 \mu \mathrm{m}$ ).

than disc retractor, higher than sulcus, rimmed, arched, and with rather flat median lobe. Disc retractor bilobed with convex sides and lower than trochal discs. Antenna rather short. Pharyngeal tube as long as trophi length. Dental formula $2 / 2$. Trunk spindle-shaped and with distinct longitudinal folds. Anal segment tapering rather abruptly to its cuff-like last quarter; posterodorsal area protruded with oblique folds and ended with truncated angular margin. Foot with 4 segments and 3 toes. Spurs conical, with straight outer margin and convex inner mar- gin, tapering abruptly to pointed tips; longer than its base width; interspace narrower than spur base width.

Body length (in creeping) $296 \mu \mathrm{m}$. Corona width $46 \mu \mathrm{m}$. Cingulum pad width $37 \mu \mathrm{m}$. Trunk width (in feeding) 61 $\mu \mathrm{m}$. Spur length $7 \mu \mathrm{m}$.

Distribution. Czech Republic and Korea.

Remarks. New to Asia. This species has never been reported again since its original description from Czech Republic until the present study. 


\section{ACKNowledgement}

I gratefully acknowledge Dr. R. Shiel, Dr. A. Örstan, Dr. C. Jersabek, and Mrs. M. Axnick (Head of Central Library of Biology, Univ. Hamburg) for their help in obtaining old references. This work was supported by a grant from the National Institute of Biological Resources (NIBR), funded by the Ministry of Environment (MOE) of the Republic of Korea (NIBR No. 2013-02-001).

\section{REFERENCES}

Bartoš, E. 1951. The Czechoslovak Rotatoria of the order Bdelloidea. Věstník čsl. zool. spol. 15:241-500.

Bartoš, E. 1959. Vírníci-Rotatoria. Fauna ČSR 15:1-969.

Bryce, D. 1915. On five species of genus Habrotrocha. J. Quekett Microsc. Club ser. 2, 12:631-642.

Chittapun, S., P. Pholpunthin and H. Segers. 1999. Rotifera from peat-swamps in Phuket province, Thailand, with the description of a new Colurella Bory de St. Vincent. Internat. Rev. Hydrobiol. 84(6):587-593.

De Manuel, J., J. LL. Pretus and D. Jaume. 1992. Rotifers from the Balearic archipelago. Hydrobiologia 239:33-41.

De Smet, W.H. 1995. Description of Encentrum dieteri sp. nov. (Rotifera, Dicranophoridae) form the High Arctic, with redescription of E. bidentatum (Lie-Pettersen, 1906) and E. murrayi Bryce, 1922. Belg. J. Zool. 125(2):349361.

De Smet, W.H. 1997. Dicranophoridae. In: Rotifera. Volume 5: The Dicranophoridae and the Ituridae (Monogononta). Guides to the identification of the microinvertebrates of the continental waters of the world. 5. pp. 1-325, 341-344.

Donner, J. 1950. Rotatorien der Humusböden. Hüllen und Gehäuse bei bdelloiden Rädertieren, besonders bei Bodenbewohnern. Österr. Zool. Zeitschr., Wien, II, 4:287-335.

Donner, J. 1954. Zur Rotatorienfauna Südmährens. Österr. Zool. Zeitschr., V, 1/2:30-117.

Donner, J. 1964. Die Rotatorien-Synusien submerser Makrophyten der Donau bei Wien und mehrere Alpenbäche. Arch. Hydrobiol./Suppl., 27, 1(3):227-324.

Donner, J. 1965. Ordnung Bdelloidea. Bestimmungsbücher zur Bodenfauna Europas 6:1-267. Akademie Verlag, Berlin.

Donner, J. 1970, Die Rädertierbestände submerser Moose der Salzach und anderer Wasser-Biotope des Flußgebietes. Arch. Hydrobiol. Suppl., 36 2/3:109-254.

Donner, J. 1972. Die Rädertierbestände submerser Moose und weiterer Merotope im Bereich der Stauraume der Donau an der deutsch-österreichischen Landesgrenze. Arch. Hydrobiol. Suppl., 44(1):49-114.

Donner, J. 1980. Einige neue Forschungen über bdelloide Rotatorien, besonders in Böden. Rev. Écol. Biol. Sol. 17(1):
125-143.

Harring, H.K. and F.J. Myers. 1924. The rotifer fauna of Wisconsin. II. A revision of the notommatid rotifers, exclusive of the Dicranophorinae. Trans. Wisc. Acad. Sci. Letters 21:416-549.

Janson, O. 1893. Versuch einer Übersicht über die RotatorienFamilie der Philodinaeen. Suppl. zum 12. Bd. der Abhandl des Naturwiss. Ver. zu Bremen. pp. 1-85.

Jersabek, C.D. 1998. Dicranophoridae (Rotifera) from the Alps. Hydrobiologia 387/388:63-77.

Jersabek, C.D. and M.F. Leitner. 2013. The Rotifer World Catalog. World Wide Web electronic publication [Available from: http://www.rotifera.hausdernatur.at/, accessed 21 Jan. 2014].

Koste, W. 1978. Die Rädertiere Mitteleuropas. Überordnung Monogononta. Begründet von M. Voigt. I. Textbd. VIII +673pp.; II. Tafelbd. II+476pp. mit 234 Tafeln, Stuttgart.

Melone, G. and C. Ricci. 1995. An uncommon bdelloid rotifer: Abrotrocha intermedia (de Beauchamp, 1909). Boll. Zool. 62:29-34.

Milne, W. 1886. On the defectiveness of the eye-spot as a means of generic distinction in the Philodinaea, with a description of two other Rotifera. Proceedings of the Philosophical Society of Glasgow. 17. p.141, pl.2, figs.5,10.

Milne, W. 1916. On the bdelloid Rotifera of South Africa. Part II, J. Quekett Micr. Club, ser. 2, 13:149-184.

Montet, G. 1915. Contribution à l'étude des Rotateurs du bassin du Léman. Revue Suisse de Zoologie. 23.

Nogrady, T. and R. Pourriot. 1995. Family Notommatidae. In: Rotifera. Volume 3: The Notommatidae and the Scaridiidae. Guides to the identification of the microinvertebrates of the continental waters of the world. 8. pp. 1-229, 239248.

Nogrady, T., R.L. Wallace and T.W. Snell. 1993. Guides to the identification of the microinvertebrates of the continental waters of the world. 4. Rotifera. Vol. 1: Biology, ecology and systematic. SPB Academic Publishing bv vii+142 pp.

Pennak, R.W. 1978. Freshwater invertebrates of the United States. $2^{\text {nd }}$ Ed. J. Wiley and Sons, New York. 803 pp.

Ricci, C.N. 1987. Ecology of bdelloids: how to be successful. Hydrobiologia 147:117-127.

Segers, H. 2007. Annotated checklist of the rotifers (Phylum Rotifera) with notes on nomenclature, taxonomy and distribution. Zootaxa 1564:1-104.

Song, M.O. 1999. Systematic study on Korean bdelloid Rotifera. Ph.D. thesis, SNU iii+200 pp.

Song, M.O. and W. Kim. 2000. Bdelloid rotifers from Korea. Hydrobiologia 439:91-101.

Song, M.O. and D.-H. Jin. 2000. Rotifer fauna of natal streams of chum salmon (Oshipcheon). J. Fish. Sci. Tech. 3(2):7177.

Stemberger, R.S. 1979. A guide to rotifers of the Laurentian 
Great Lakes. US Environmental Protection Agency, Cincinnati, Ohio. $185 \mathrm{pp}$.

The Korean Society of Systematic Zoology, 1997. List of animals in Korea (excluding insects). Academy Press. 489pp. (in Korean).

Zhuge, Y., X. Huang and W. Koste. 1998. Rotifera recorded from China, 1893-1997, with remarks on their composition and distribution. Internat. Rev. Hydrobiol. 83(3):217232.

Submitted: December 2, 2013, Accepted: January 21, 2014 